\title{
Fusarium-Induced Diseases of Tropical, Perennial Crops
}

\author{
Randy C. Ploetz
}

University of Florida, Department of Plant Pathology, Tropical Research \& Education Center, 18905 SW 280 th Street, Homestead 33031. Accepted for publication 14 December 2005.

\begin{abstract}
Ploetz, R. C. 2006. Fusarium-induced diseases of tropical, perennial crops. Phytopathology 96:648-652.

The world's oldest ecosystems are found in the tropics. They are diverse, highly evolved, but barely understood. This and subsequent papers describe diseases of tropical, perennial plants that are caused by Fusarium spp. Many of these are economically significant, difficult to manage, and of scientific interest. Some represent coevolved pathosystems (e.g., Panama disease, tracheomycosis of coffee, fusariosis of pineapple, and Fusarium wilt of oil palm), whereas others may be newencounter diseases or are caused by generalist pathogens (cushion gall of cacao). New vector relationships are evident in other pathosystems (e.g.,
\end{abstract}

ABSTRACT mango malformation), and two or more pathogens have been shown to cause some of the diseases (Panama disease and tracheomycosis of coffee). More work on these pathosystems is warranted as they could reveal much about the evolution of plant pathogens and the important diseases they cause.

Additional keywords: Albonectria rigidiuscula, Fusarium circinatum, $F$. decemcellulare, $F$. guttiforme, $F$. mangiferae, $F$. oxysporum, $F$. proliferatum, F. sacchari, F. semitectum, F. solani, F. subglutinans, F. xylarioides, Gibberella circinata, G. sacchari, G. xylarioides, Nectria haematococca, pitch canker, pokkah boeng.
Fusarium spp. are common associates of higher plants and are among the most ubiquitous fungi in terrestrial ecosystems. It has been suggested that "If it is green, there is some Fusarium that can grow on it, in it, or with it" (26).

Fusarium spp. are significant plant pathogens, and the diversity of affected hosts, numbers of pathogen taxa, and types of habitats in which the resultant diseases are found is unparalleled in plant pathology $(7,18,26,34)$. Diseases that these fungi cause in temperate agricultural zones have received an enormous amount of attention, most of which has focused on annual crops; the recent flurry of activity that has surrounded the reemergence of Fusarium head blight on wheat is a prime example $(25,67)$.

Far less research has been conducted on Fusarium-induced diseases in the tropics, and even less attention has focused on those that occur on perennial hosts. The latter diseases are among the most important and scientifically significant of all plant diseases $(10,11,23,43)$. The infamous Panama disease of banana, caused by $F$. oxysporum f. sp. cubense, has been cited as one of the six most important plant diseases and was responsible for billions of dollars in losses in the first export trades $(48,53)$. A new race of the pathogen threatens current export and subsistence production of this most important fruit $(47,48)$. Fusarium wilt of oil palm, caused by $F$. oxysporum f. sp. elaeidis, would devastate production of this significant vegetable oil crop if it moved to the major Southeast Asian production areas $(14,23)$. And bakanae, the foolish disease of rice, played a major role in the early study of plant

Corresponding author: R. C. Ploetz; E-mail address: rcp@ifas.ufl.edu

DOI: 10.1094/PHYTO-96-0648

(C) 2006 The American Phytopathological Society hormones (43). In 1939, the principles that are responsible for the symptoms of bakanae, the gibberellins, were first isolated from cultures of the bakanae pathogen, F. fujikuroi.

At the 2005 annual meeting in Austin, a symposium was held on Fusarium-induced diseases of tropical, perennial crops $(3,14,19,29,48,51)$. This article provides a brief narrative on the tropics, introduces the symposium topic, and discusses diseases that were not covered in Austin.

The tropics and tropical crops. The tropics are designated in several ways, but are usually defined as lying between the Tropics of Cancer and Capricorn (respectively, the latitudes of $23^{\circ} 27^{\prime}$ north and south) $(4,20,30,58,65)$. Different definitions also exist for what constitutes a tropical plant. For example, Wellman (65) suggested that locations in which cold-sensitive plants grew could be used to define the tropics, but plants he cited, the palms, unfortunately contain species that tolerate freezing temperatures (16). Tropical crops vary in their response to elevation as well as latitude, and there is no single set of conditions under which all of them thrive $(30,49,50)$. For some, such as cacao, Theobroma cacao, low temperatures restrict major production to low elevations near the equator. Others, such as some species of passion fruit, Passiflora spp., must be grown at high elevations in the tropics because they do not tolerate high nighttime temperatures. Diverse temperate crops are grown in the tropics at high elevations, whereas others of temperate origin are produced at lower elevations; members of Cruciferae and Leguminosae are especially common. Commercial tropical crops are often most important outside their native ranges; in these cases, the absence of important coevolved pathogens is significant.

Fusarium-induced diseases of tropical, perennial crops. Diverse Fusarium taxa affect perennial crops in the tropics (Table 1). The responsible taxa fall into five of the nine species that 
Snyder and Hansen considered in their, admittedly, lumped concept of the genus (55). Some of these fungi produce teleomorphs in nature (Gibberella xylarioides/coffee wilt), whereas others do so rarely (G. sacchari/pokkah boeng of sugarcane) or only in the laboratory (Albonectria rigidiuscula/cushion gall of cacao and G. circinata/pitch canker of pine) $(15,19,23,27,31)$. No teleomorph is known for most of these pathogens. The latter fungi have been assumed to reproduce clonally, but recombination has been revealed in at least one taxon, F. oxysporum f. sp. cubense (57).

Despite their diverse etiologies, these diseases share several attributes. Seven in Table 1 are caused by formae speciales of F. oxysporum, a species complex that contains numerous phylogenetically distinct taxa (38); many of the formae speciales coevolved with their respective hosts. Many of these diseases have similar epidemiologies and disease cycles. With the possible exceptions of crown rot of banana and cushion gall of cacao, transmission of the pathogens occurs via seed and vegetative propagules. This is especially important for the vascular wilts, which are moved most effectively by man in infested materials. Where soils are contaminated with the wilt pathogens, susceptible crops often cannot be produced for decades. The long-term survival of at least some of the Fusarium wilt pathogens involves alternative weed host reservoirs (62). The disease cycles of several of the diseases, including cushion gall of cacao, mango malformation, canker of passion fruit, pitch canker of pine, and fusariosis of pineapple, involve insects and acarids that act as vectors and/or wounding agents $(23,44,45)$.

Most of these diseases are difficult to manage. Although fungicides are used to control crown rot of banana and fusariosis of pineapple, they are ineffective against the vascular wilts. Fumigants that are helpful against Fusarium wilts on annual crops are not efficacious for perennials since the pathogens recolonize treated soil rapidly (22). Pathogen-free propagation materials and host resistance are the principal means by which most of these problems are addressed.

Notable Fusarium-induced diseases of tropical, perennial crops are listed in Table 1. Although the list is believed to be current, future findings will undoubtedly change the taxonomy and nomenclature of some of the causal agents, alter the etiology of some of the diseases, and add new diseases. Discussed below are several of the diseases in Table 1 that were not addressed during the symposium.
Abacá, Musa textilis. Abacá, M. textilis, originated in the Philippines and Borneo (50,54). It is an important cordage fiber that is well suited to marine applications. Although synthetic fibers have become more important in recent years, abacá remains a significant commodity in the tropics. In 2004, world production totaled 97,880 metric tons (2).

Fusarium wilt. Fusarium wilt is caused by $F$. oxysporum f. sp. cubense, cause of Panama disease. A Philippine isolate from abacá was in vegetative compatibility group (VCG) 0123 , members of which also affect dessert and cooking bananas $(5,47)$.

Symptoms are described in the following paper on Panama disease (48). The disease on abacá kills plants and affects fiber color and strength. Until its demise in the mid-1900s, commercial production was affected in Central America, and the crop is still impacted in the Philippines (61).

Simmonds (54) indicated that little improvement of the crop had occurred. 'Bungalonon', 'Maguindinao', and 'Tangoñgon' are susceptible, whereas 'Putian' and canton hybrids (M. balbisiana $\times$ M. textilis) are resistant (50).

Banana, Musa spp. The origins and importance of banana are discussed in the following article on Panama disease (48).

Crown rot. Crown rot is a problem on exported bananas $(45,56)$. The crown area of the hands of these fruit is exposed during their removal from the bunch peduncle (Fig. 5 in literature citation 48). This wounded surface enables entry of a diverse suite of postharvest pathogens (45).

Crown rot causes significant esthetic damage to and drop of fingers (56). It begins as a softening and blackening of tissues at the cut crown surface and spreads rapidly during ripening. Watersoaked, dark bands of creased and bruised tissue can develop if pedicels are flexed during handling; they turn black, enlarge and wither; decay can eventually extend into the fruit pulp.

Numerous fungi have been reported on banana fruit, including at least six species of Fusarium: F. camptoceras, F. concentricum, F. musarum, F. proliferatum, F. semitectum (syn. F. pallidoroseum), and $F$. subglutinans sensu lato $(26,45)$. There is confusion over which species cause crown rot. To date, pathogenicity tests have not been performed with $F$. concentricum and $F$. musarum, and although $F$. camptoceras has been recovered from decayed bananas, it is a presumed saprophyte (26). Additional work is needed to determine the extent to which $F$. proliferatum and $F$. semitectum may be involved and whether additional species

TABLE 1. Notable diseases of tropical, perennial crops that are caused by Fusarium spp.

\begin{tabular}{|c|c|c|c|}
\hline Host $^{\mathrm{a}}$ & Disease & $\operatorname{Agent}(\mathrm{s})^{\mathrm{b}}$ & Selected references \\
\hline Abacá, Musa textilis & Fusarium wilt & F. oxysporum f. sp. cubense & (61) \\
\hline Angsana, Pterocarpus indicus & Wilt & F. oxysporum f. sp. angsanae & $(8,12,13)$ \\
\hline Banana, Musa spp. & Panama disease (Fusarium wilt) & F. oxysporum f. sp. cubense & $(46-48)$ \\
\hline Cacao, Theobroma cacao & Cushion gall & F. decemcellulare (Albonectria rigidiuscula) & $(15,21,23)$ \\
\hline Cassava, Manihot esculenta & Root rot & F. solanic & (3) \\
\hline Coffee, Coffea spp. & Wilt (tracheomycosis) & F. xylarioides (Gibberella xylarioides) & $(17,51)$ \\
\hline Cotton, Gossypium spp. & Fusarium wilt & F. oxysporum f. sp. vasinfectum & $(23)$ \\
\hline \multirow[t]{2}{*}{ Passion fruit, Passiflora spp. } & Fusarium wilt & F. oxysporum f. sp. passiflorae & (45) \\
\hline & Canker & F. solanic ${ }^{\mathrm{c}, \mathrm{d}}$ and others? & $(42,45)$ \\
\hline Pepper, Piper nigrum & Yellows or slow decline & F. solani ${ }^{\mathrm{c}}$ & (41) \\
\hline Pine, Pinus spp. & Pitch canker & F. circinatum (MP H, G. circinata) & (19) \\
\hline Pineapple, Ananas comosus & Fusariosis & F. guttiforme & $(43,45,60)$ \\
\hline Rosella, Hibiscus sabdariffa var. sabdariffae & Fusarium wilt & F. oxysporum f. sp. rosellae & $(39,40)$ \\
\hline Sugarcane, Saccharum officinarum & Pokkah boeng & F. sacchari (MP B, G. sacchari) & $(32,66)$ \\
\hline
\end{tabular}

a Although pines occur primarily in temperate climates, significant production is found, and pitch canker may have originated, in the tropics (19). Although most cultivated cottons are annual, many species of Gossypium are perennial and ancestral to several of the cultivated forms $(52,54)$.

b When they are known, teleomorphs are listed in parentheses after the Fusarium anamorph. Mating populations (MPs) of the G. fujikuroi species complex are listed with the currently recognized name for the anamorph and teleomorph. Circumstantial evidence suggests that $F$. sterilihyphosum and at least two other unnamed species may cause mango malformation, in addition to F. mangiferae.

${ }^{\mathrm{c}} F$. solani is a species complex that contains at least 50 distinct taxa (36).

$\mathrm{d}$ The name of the homothallic teleomorph of this pathogen is controversial (33). To avoid confusion, only the anamorph is used in this table. 
play roles (note that Nirenberg and O'Donnell [35] described $F$. concentricum for isolates from banana that were previously described as $F$. subglutinans sensu lato).

Several of the associated species produce mycotoxins (26): F. concentricum produces moniliformin and beauvericin; F. musarum produces trichothecenes such T-2 and HT-2; F. proliferatum produces beauvericin, fumonisins, fusaproliferin, fusaric acid, fusarins, and moniliformin; and $F$. semitectum produces apicidins, beauvericin, equisetin, fusapyrone, moniliformin, sambutoxin, trichothecenes, and zearalenone. In addition, isolates of F. moniliforme from banana fruit produced trichothecenes and zearalenone in India (9). The latter isolates were probably F. semitectum, given this toxin profile, the prior use of this name for $F$. subglutinans sensu lato, and the frequent confusion of the later taxon with F. semitectum (26).

The toxigenicity of these species has been tested on nonbanana substrates (e.g., maize cultures). Whether these species produce mycotoxins in banana and colonize fruit to the extent that they represent bona fide human health risks has not been investigated.

The causal fungi are common on banana, sporulate on decaying debris, and are disseminated by wind and water-splash (56). Infection occurs primarily at the cut surfaces of crowns. The use of dull knives during trimming causes ragged edges and favors entry of crown rot organisms into adjacent, sound tissue.

The management of crown rot was reviewed recently (24). Postharvest treatment with fungicides is usually essential. Other measures include hot water $\left(50^{\circ} \mathrm{C}\right)$ dips, retrimming the crown surface, and using controlled atmospheres and various fruit coatings.

Cacao, Theobroma cacao. Cacao, T. cacao, has been cultivated for millennia in the Americas (52,54). For the Maya, the crop had divine origins that Linnaeus recognized when he named the genus.

Beans (seed) of cacao, the source of chocolate, are major export commodities. In 2003, global production estimated at ca. 3.4 million metric tons was valued at $\$ 4.4$ billion (2). About $75 \%$ of all production occurs in West Africa.

Cushion gall. Cushion gall is a disease of young and mature cacao trees. It occurs in Sri Lanka, West Africa, and the Western Hemisphere, and was economically important in Colombia, Costa Rica, and Nicaragua (21).

Tight, knotted galls are formed on stems and branches, and stagheads can develop on branches. Dieback caused by the pathogen may result from complex interactions with other pathogens and pests.

F. decemcellulare causes cushion gall. Homothallic and heterothallic isolates of the teleomorph, Albonectria (syn: Calonectria) rigidiuscula, have been reported on cacao, but only heterothallic strains cause galls $(15,23)$; perithecial isolates on cacao were homothallic and nonpathogenic (15). Recently, a dichotomous key on this and related nectria-like fungi was published (63).

F. decemcellulare is found on diverse trees in the tropics (26). It is weakly aggressive and requires wounds to infect cacao (23). Capsid bugs, mainly Distantiella theobromae and Sahlbergella singularis, facilitate infection and are important factors in the cushion gall disease cycle. The pathogen also interacts with damage caused by other pathogens, such as Diplodia theobromae and Phytophthora palmivora.

Passion fruit, Passiflora spp. The Passifloraceae contains about 500 species and 12 genera $(31,49)$. The mainly New World genus, Passiflora, contains about 400 species, only a few of which are significant as fruit crops (31).

Canker. Canker probably occurs wherever this crop is grown (45). This disease has been confused with Fusarium wilt, whose symptoms it resembles. Initially, canker reduces shoot elongation (42). Affected terminals wilt or dieback and a sudden and terminal collapse of vines is common. Leaves on affected vines wilt and yellow, but usually do not abscise. Fruit also remain attached. Concave cankers to $10 \mathrm{~cm}$ in length form at the soil line or where vines are tied to trellises. All vines in affected plantings usually die within 5 years. Crimson perithecia of the pathogen form on diseased tissues in the field.

The pathogen is a member of the $F$. solani species complex, which contains at least 50 phylogenetically distinct taxa (36). It has a homothallic teleomorph whose name is confused; it is most often referred to as Nectria haematococca, but the genera Haematonectria and Neocosmospora have also been indicated $(33,37$, 45). To avoid confusion, only the $F$. solani anamorph will be used in this review.

Other species of Fusarium that have been associated with canker include $F$. avenaceum, $F$. graminearum, $F$. lateritium, $F$. redolens, and F. sambucinum (45). It is not clear whether Koch's postulates have been completed with any of the latter fungi.

The $F$. solani from passion fruit is not aggressive, and wounding has a profound effect on disease development (45). The onset of symptoms is hastened, and the incidence and severity of the disease is increased, if vines are wounded prior to inoculation. Ants of the genera Solenopsis and Cromatogaster may play a role in disease development in Venezuela, and the disease is known to interact with Phytophthora blight.

The pathogen colonizes the host in advance of visible symptoms and can be moved in healthy nursery stock or by cuttings from asymptomatic plants (45). When cuttings are used to propagate the crop, pathogen-free stock must be used. Effective chemical measures have not been described. Tolerance increases as plants age, and resistance has been reported in Passiflora edulis f. flavicarpa, P. maliformis, and Passiflora ex Queensland 'Queensland Purple'.

Fusarium wilt. Fusarium wilt was a major disease of $P$. edulis $\mathrm{f}$. edulis in Australia prior to the use of resistant rootstocks (45). The disease may also be present in Brazil, Malaysia, and South Africa. Due to their similar symptoms, it is unclear whether canker or Fusarium wilt is described in some reports.

The first external symptom is pale new growth that progresses to a wilt of one or more shoots (23). Symptoms may be unilateral or encompass the entire plant, and fruit shrivel and remain attached to the vine if they are immature. Vascular browning may extend $2 \mathrm{~m}$ above the soil line, which is higher than that associated with canker. In addition, cankers do not develop on plants affected by Fusarium wilt. Eventually, the disease kills plants.

F. oxysporum f. sp. passiflorae causes Fusarium wilt of passion fruit (45). P. foetida, P. ligularis, P. mollissima, and probably other species are susceptible, whereas $P$. caerulea, $P$. edulis $\mathrm{f}$. flavicarpa, $P$. herbertiana, $P$. incarnata, and $P$. suberosa are resistant (45).

Pineapple, Ananas comosus. Pineapple, Ananas comosus, originated in South America (54). It is important throughout the tropics. Over 15 million metric tons were harvested in 2004, and Thailand and the Philippines were the leading producers (2). Like many tropical crops, only a small portion of pineapple production is exported. In 2003, 1.6 million metric tons of fresh fruit worth $\$ 841$ million was traded internationally, and 1.2 million metric tons worth $\$ 650$ million was exported in cans.

Fusariosis. Fusariosis is a most destructive disease of pineapple $(43,45)$. It was first observed in Argentina and Brazil, and is now found in Bolivia, Paraguay, and Uruguay. It has reduced output in the former leading producer, Brazil, to third place in the world and would have a great impact if it were disseminated outside South America.

Fusariosis affects virtually all parts of the plant, but is most destructive on fruit (45). Affected areas on fruit appear off-color, become sunken, light to dark brown, and are covered with mycelium of the pathogen and a brownish exudate. Plants have bent or dead apices, shortened stems, disrupted phylotaxy, and are stunted and chlorotic.

The cause of fusariosis is confusing. F. subglutinans sensu lato ( $F$. moniliforme and $F$. moniliforme var. subglutinans in old reports) is indicted in most reports, but the same taxon was impli- 
cated in fruitlet core rot, a less severe disease that is found outside the range of fusariosis (e.g., Hawaii) (45). Ventura (60) proposed that the fusariosis pathogen be recognized as a new taxon, $F$. subglutinans f. sp. ananas. Subsequently, a new species, F. guttiforme, was described for nine isolates from Brazil, some of which came from Ventura, as well as at least one isolate from Hawaii (35). Thus, F guttiforme includes both fusariosis and fruitlet core rot pathogens. Although $F$. guttiforme is preferable to $F$. subglutinans, which now refers to only the anamorph of $G$. subglutinans (a pathogen of maize), work is needed to distinguish the fusariosis and fruitlet core rot pathogens.

Although infection can occur at all stages of flowering, early infection causes the most severe disease (45). Wounding enhances disease development, and insect damage, particularly by the pineapple caterpillar, Thecla basilides, is thought to play an important role.

Infected slips and suckers are common means for dispersing the pathogen (45). Within field, spread is primarily via insects and wind. Since the fungus can survive in soil for several months, infested fields should not be immediately replanted to pineapple.

Major losses occur in Brazil on 'Pérola', 'Jupi', and 'Smooth Cayenne' (45). Incidence on fruit can be as high as $75 \%$. Scant research has been conducted on the use of resistant cultivars. The disease is managed with clean propagation material, insect control, and protection of the inflorescence and developing fruit with fungicides.

Sugarcane, Saccharum. Sugarcanes are $\mathrm{C}_{4}$ perennial grasses that originated in the eastern tropics. Their center of diversity is New Guinea and two wild species, Saccharum robustum and $S$. spontaneum, contributed to the domesticated forms $(50,54)$. In 2004 , over 1.3 billion metric tons was harvested; the leading producers, Brazil and India, were responsible for approximately half of this total (2).

Pokkah boeng. This disease was originally described in Java in 1896, where it caused serious losses $(32,66)$. Pokkah boeng occurs worldwide, reduces the quality of the harvested crop and can produce spectacular outbreaks. However, the use of resistant clones has reduced its importance.

The disease produces a wide range of symptoms, particularly during rainy weather $(32,66)$. Most commonly, plant apices are twisted and malformed (the disease's common name describes these symptoms in Javanese). Leaves are chlorotic on the underside, narrowed at the base, and may develop dark red sectors. Susceptible cultivars can develop more severe symptoms, including apical necrosis, wrinkling and shortening of leaves, and ladderlike lesions on the sheaths and midribs that may deepen on the stem to resemble knife cuts.

F. sacchari causes pokkah boeng. The pathogen was described in 1913, and was neotypified in 2005 (27). The pathogen is also found on sorghum in the Philippines and Mexico, and occasionally on maize and orchids. F. sacchari can be confused with F. subglutinans and related species, and is not identified reliably without mating tests or molecular markers. The teleomorph of F. sacchari, G. sacchari, is heterothallic (27). Its ascospores are larger than those of most of the other Gibberella spp.

The pathogen is spread in wind-blown rain, infected cane cuttings, and pupae and adults of sugarcane stem borers $(26,66)$. Cane is most susceptible between 3 and 8 months of age $(32,66)$. Late applications of nitrogen that enhance growth increase damage, and satisfactory control relies on the use of resistant cultivars.

Vanilla, Vanilla planifolia. Vanilla, V. planifolia, is the only orchid that produces an edible product, vanilla (64). It is indigenous to Central America and Mexico, but most commercial production occurs in Madagascar and Indonesia. In 2003, world imports of 6,715 metric tons of vanilla pods were worth more than $\$ 500$ million (2).

Stem and root rot. Stem and root rot limits production in China, India, Indonesia, Puerto Rico, and probably other areas in which the crop is produced $(1,6,28,64)$. Root and stem necrosis reduce shoot growth and cause wilting and desiccation. Stress plays an important role, and plants with inadequate shade, excessive pods, and deficient water and nutrients are impacted most severely.

The disease is caused by F. oxysporum f. sp. vanillae (F. batatis var. vanillae in the first reports from Puerto Rico). Work in Indonesia identified two VCGs of the pathogen (59).

The fungus survives long periods in soil and makes replanting in infested soils impossible (6). It also latently infects vines and, thus, can be disseminated in asymptomatic rooted cuttings (1). $V$. pompona, West Indian vanilla, and V. phaeantha, Tahitian vanilla, are supposedly resistant and hybridize with $V$. planifolia (64).

Conclusions. In general, inadequate research has been conducted on diseases of tropical plants $(58,63)$. Ecosystems and agricultural production are incredibly important in the tropics, and our understanding is deficient on the numbers, types, and management of plant diseases that occur in this region.

The preceding descriptions provide cursory coverage of tropical plant diseases that are caused by Fusarium spp. The list in Table 1 appears to be short and incomplete considering the array of plants that grow in the tropics and the diversity that is recognized in this genus $(7,18,26,34)$. Undoubtedly, there are new Fusarium taxa as well as new diseases that await discovery. More work on tropical pathosystems is warranted as it could reveal much about the evolution of plant pathogens and the important diseases they cause.

\section{ACKNOWLEDGMENTS}

An anonymous reviewer is thanked for taxonomic information on some of the above pathogens.

\section{LITERATURE CITED}

1. ACIAR. 2004. Australian Centre for International Research. ACIAR Project Summary CP/2000/094.

2. Anonymous. 2005. FAOSTAT. FAO Statistical Database. http://faostat.fao.org/

3. Bandyopadhyay, R., Mwangi, M., Aigbe, S. O., and Leslie, J. F. 2006. Fusarium spp. from the cassava root rot complex in West Africa. Phytopathology 96:673-676.

4. Bates, M. 1952. Where Winter Never Comes. Scribner, New York.

5. Bentley, S., Pegg, K. G., Moore, N. Y., Davis, R. D., and Buddenhagen, I. W. 1998. Genetic variation among vegetative compatibility groups of Fusarium oxysporum f. sp. cubense analyzed by DNA fingerprinting. Phytopathology 88:1283-1293.

6. Ben Yephet, Y., Dudai, N., Chaimovitsh, D., and Havkin-Frenkel, D. 2003. Control of vanilla root rot disease caused by Fusarium. Abstract of poster presented at First International Congress on the Future of the Vanilla Business. Vanilla 2003. Archived at http://www.aesop.rutgers.edu/ $\sim$ vanilla2003/posters.htm

7. Booth, C. 1971. The Genus Fusarium. Commonwealth Mycological Institute, Kew, England.

8. Burkhill, I. M. 1966. A Dictionary of the Economic Products of the Malay Peninsula, Vol. I and II. Ministry of Agriculture and Cooperative, Kuala Lumpur, Malaysia.

9. Chakrabarti, D. K., and Ghosal, S. 1986. Occurrence of free and conjugated 12,13-epoxytrichothecenes and zearalenone in banana fruits infected with Fusarium moniliforme. Appl. Environ. Microbiol. 51:217-219.

10. Cook, A. A. 1975. Diseases of Tropical and Subtropical Fruits and Nuts. Hafner Press, New York.

11. Cook, A. A. 1981. Diseases of Tropical and Subtropical Field, Fiber and Oil Plants. Hafner Press, New York.

12. Corner, E. J. H. 1988. Wayside Trees of Malaya. Vol. I. 3rd ed. Malayan Nature Society.

13. Crowhurst, R. N., King, F. Y., Hawthorne, B. T., Sanderson, F. R., and Choi-Pheng, Y. 1995. RAPD characterization of Fusarium oxysporum associated with wilt of angsana (Pterocarpus indicus) in Singapore. Mycol. Res. 99:14-18.

14. Flood, J. 2006. A review of Fusarium wilt of oil palm caused by Fusarium oxysporum f. sp. elaedis. Phytopathology 96:660-662.

15. Ford, E. J., Bourret, J. A., and Snyder, W. C. 1967. Biologic specialization in Calonectria (Fusarium) rigidiuscula in relation to green point gall of cocoa. Phytopathology 57:710-712. 
16. Franko, D. A. 2003. Palms Won't Grow Here and Other Myths: WarmClimate Plants for Cooler Areas. Timber Press, Portland, OR.

17. Geiser, D. M., Lewis Ivey, M. L., Hakiza, G., Juba, J. H., and Miller, S. A. 2005. Gibberella xylarioides (anamorph: Fusarium xylarioides), a causative agent of coffee wilt disease in Africa, is a previously unrecognized member of the G. fujikuroi species complex. Mycologia 97:191-201.

18. Gerlach, W., and Nirenberg, H. 1982. The Genus Fusarium-A Pictorial Atlas. Paul Parey, Berlin and Hamburg.

19. Gordon, T. R. 2006. Pitch canker disease of pines. Phytopathology 96:657-659.

20. Gourou, P. 1961. The Tropical World. Wiley, New York.

21. Hansen, A. J. 1966. Fusaria as agents of cacao green point cushion gall in the Caribbean and in Latin America. Plant Dis. Rep. 50:229-233.

22. Herbert, J. A., and Marx, D. 1990. Short-term control of Panama disease of bananas in South Africa. Phytophylactica 22:339-340.

23. Holliday, P. 1980. Fungus Diseases of Tropical Crops. Cambridge University Press, Cambridge.

24. Krauss, U., and Johanson, A. 2000. Recent advances in the control of crown rot of banana in the Windward Islands. Crop Prot. 9:151-160.

25. Leonard, K. J., and Bushnell, W. R. (eds.) 2003. Fusarium Head Blight of Wheat and Barley. The American Phytopathological Society, St. Paul, MN.

26. Leslie, J. F., and Summerell, B. A. 2006. The Fusarium Lab Manual. Blackwell, Ames, IA.

27. Leslie, J. F., Summerell, B. A., Bullock, S., and Doe, F. J. 2005. Description of Gibberella sacchari and neotypification of its anamorph Fusarium sacchari. Mycologia 97:718-724.

28. Liew, E. C. Y., Rondonuwu, F., Pinaria, A., Sembel, D. T., Summerell, B. A., and Burgess, L. W. 2004. Fusarium stem rot of vanilla in North Sulawesi. (Abstr.) Phytopathology 94(suppl.):S61.

29. Marasas, W. F. O., Ploetz, R. C., Wingfield, M. J., Wingfield, B. D., and Steenkamp, E. T. 2006. Mango malformation disease and the associated Fusarium species. Phytopathology 96:667-672.

30. Martin, F. W. (ed.) 1984. Handbook of Tropical Food Crops. CRC Press, Boca Raton, FL.

31. Martin, F. W., and Nakasone, H. Y. 1970. The edible species of Passiflora. Econ. Bot. 24:333-343.

32. Martin, J. P., Handojo, H., and Wismer, C. A. 1989. Pokkah boeng. Pages 157-165 in: Disease of Sugarcane. Major Diseases. C. Ricaud, B. T. Egan, A. G. Gillaspie, Jr., and C. G. Hughes, eds. Elsevier Science Publishers, Amsterdam.

33. Nalim, F. A. 2004. Studies in molecular phylogenetics of Fusarium species. Ph.D. thesis. Pennsylvania State University, University Park, PA.

34. Nelson, P. E., Tousson, T. A., and Marasas, W. F. O. 1983. Fusarium Species: An Illustrated Manual for Identification. Pennsylvania State University Press, University Park, PA.

35. Nirenberg, H. I., and O'Donnell, K. 1998. New Fusarium species and combinations within the Gibberella fujikuroi species complex. Mycologia 90:434-458.

36. O'Donnell, K. 1996. Progress towards a phylogenetic classification of Fusarium. Sydowia 48:57-70.

37. O'Donnell, K. 2000. Molecular phylogeny of the Nectria haematococcaFusarium solani species complex. Mycologia 92:919-938.

38. O’Donnell, K., and Cigelnik, E. 1999. A DNA sequence-based phylogenetic structure for the Fusarium oxysporum species complex. Phytoparasitica 27:69.

39. Ooi, K. H., and Salleh, B. 1999. Vegetative compatibility groups of Fusarium oxysporum, the causal organism of vascular wilt on roselle in Malaysia. Biotropia 12:31-41.

40. Ooi, K. H., Salleh, B., Hafiza, M. H., and Zainal, A. A. A. 1999. Interaction of Fusarium oxysporum with Meloidogyne incognita on Rosella. J. Indon. Plant Prot. 5:83-90.

41. Pereira, J. L. 1983. Importancia patologica relativa de Fusarium e Phytophthora na cultura da pimenta do reino na Bahia, Brasil. (Relative pathological importance of Fusarium and Phytophthora in the cultivation of black pepper in Bahia, Brazil.) Rev. Theobroma 13:175-181.

42. Ploetz, R. C. 1991. Nectria haematococca causes sudden wilt of passion fruit in south Florida. Plant Dis. 75:1071-1073.

43. Ploetz, R. C. 2001. Diseases of tropical crops caused by Fusarium spp. Pages 295-309 in: Fusarium: Paul E. Nelson Memorial Symposium. B. A. Summerell, J. F. Leslie, D. Backhouse, and W. L. Bryden, eds. The American Phytopathological Society, St. Paul, MN

44. Ploetz, R. C. 2001. Malformation: A unique and important disease of mango, Mangifera indica L. Pages 233-247 in: Fusarium: Paul E. Nelson Memorial Symposium. B. A. Summerell, J. F. Leslie, D. Backhouse, and W. L. Bryden, eds. The American Phytopathological Society, St. Paul, $\mathrm{MN}$.

45. Ploetz, R. C. (ed.) 2003. Diseases of Tropical Fruit Crops. CABI Publishing, Wallingford, UK.

46. Ploetz, R. C. 2005. Panama disease, an old nemesis rears its ugly head: Part 1, the beginnings of the banana export trades. Online. Plant Health Progress doi: 10.1094/PHP-2005-1221-01-RV.

47. Ploetz, R. C. 2006. Panama disease, an old nemesis rears its ugly head: Part 2, the cavendish era and beyond. Online. Plant Health Progress doi: 10.1094/PHP-2006-0308-01-RV.

48. Ploetz, R. C. 2006. Fusarium wilt of banana is caused by several pathogens referred to as Fusarium oxysporum f. sp. cubense. Phytopathology 96:653-656.

49. Purseglove, J. W. 1985. Tropical Crops. Dicots. Longman, London.

50. Purseglove, J. W. 1985. Tropical Crops. Monocots. Longman, London.

51. Rutherford, M. A. 2006. Current knowledge of coffee wilt disease, a major constraint to coffee production in Africa. Phytopathology 96:663666.

52. Sauer, J. D. 1993. Historical Geography of Crop Plants. CRC Press, Boca Raton, FL.

53. Simmonds, N. W. 1966. Bananas. 2nd ed. Longman, London.

54. Simmonds, N. W. (ed.) 1976. Evolution of Crop Plants. Longman, London.

55. Snyder, W. C., and Hansen, H. N. 1940. The species concept in Fusarium. Am. J. Bot. 27:64-67.

56. Stover, R. H. 1972. Banana, Plantain, and Abaca Diseases. Commonwealth Mycological Institute, Kew, Surrey, UK.

57. Taylor, J. W., Jacobson, D. J., and Fisher, M. C. 1999. The evolution of asexual fungi: Reproduction, speciation and classification. Annu. Rev. Phytopathol. 37:197-246.

58. Thurston, H. D. 1998. Tropical Plant Diseases. 2nd ed. The American Phytopathological Society, St. Paul, MN.

59. Tombe, M., Kobayashi, K., and Ogoshi, A. 1994. Vegetative compatibility grouping of Fusarium oxysporum f. sp. vanillae in Indonesia. Indon. J. Crop Sci. 9:29-39.

60. Ventura, J. A. 1994. Pineapple fusariosis: Characterization of the pathogen, epidemiology of the disease, resistance and micropropagation of the host in vitro. Ph.D. thesis. University of Viçosa, Brazil.

61. Waite, B. H. 1954. Vascular disease of abaca or Manila hemp in Central America. Plant Dis. Rep. 38:575-578.

62. Waite, B. H., and Dunlap, V. C. 1953. Preliminary host range studies with Fusarium oxysporum f. sp. cubense. Plant Dis. Rep. 37:79-80.

63. Watling, R., Frankland, J. C., Ainsworth, A. N., Isaac, S., and Robinson, C. H. (eds.) 2002. Tropical Mycology, Vol. 2, Micromycetes. CABI Publishing, Wallingford, UK.

64. Weiss, E. A. 2002. Vanilla diseases. Page 145 in: Spice Crops. CABI Publishing, Wallingford, UK.

65. Wellman, F. L. 1962. A few introductory features of tropical plant pathology. Phytopathology 52:928-930.

66. Whittle, P. J. L., and Irawan. 2000. Pokkah boeng. Pages 136-140 in: A Guide to Sugarcane Diseases. P. Rott, R. A. Bailey, J. C. Comstock, B. J. Croft, and A. S. Saumtally, eds. CIRAD/ISSCT, Montpellier.

67. Windels, C. E. 2000. Economic and social impacts of Fusarium head blight: Changing farms and rural communities in the Northern Great Plains. Phytopathology 90:17-21. 